\title{
CHILD PORNOGRAPHY AND CHILD ABUSE IN CYBERSPACE
}

\author{
Alin Teodorus Drăgan \\ "Vasile Goldiş" Western University of Arad \\ E-mail: alinteodorus@yahoo.co.uk
}

(Received: April 2018; Accepted: June 2018)

\begin{abstract}
In the course of time, it has been demonstrated that the Internet is a vulnerable system, and this aspect, combined with the advantages it offers (storage, processing and transmission of huge amounts of data, accessibility, ease of use, distance-independence, the possibility of applications in the business field), have resulted in a favourable context for criminal activities, triggering the emergence of a new criminal phenomenon - cybercrime.
\end{abstract}

Key words: child pornography, minors, computer systems, Internet

\section{Introduction}

Child pornography was known before the advent of the internet, but technological advances have led to a rapid increase in the production and distribution of this type of pornography worldwide. Images can be produced, copied and delivered now within a fraction of a second, whereas, in the past, such materials had to be developed and delivered.

\section{Luring and seduction as methods of action of pedophiles}

Luring is a process through which a pedophile is trying to prepare a child for a future physical relationship by overcoming some of the barriers he will have to face for such a relationship. When a pedophile encounters a child and considers him/her susceptible for sexual intercourse, he will initiate a process designed to gain the child's trust. During this process, such individuals destroy the child's protection system, and then manipulate the child in such a way as to make him/her believe that a physical relationship with an adult is an acceptable form of relationship. After establishing a certain level of confidence, the pedophile will try to have the child engage in an attempt to perform a desired sexual activity [1].

Throughout history, schools, malls, and playgrounds have been preferred places for recruiting minor victims, and social networking chat platforms are nowadays additional sources that pedophiles can use in order to locate a potential minor victim.

Most of the times, a child targeted as a potential victim comes from a home where he/she suspects he/she is not loved or is not given enough attention. Pedophiles who locate such a child will often try to convince him/her that he/she is respected by them, thus convincing the minor victim that he/she is loved and understood. 
As a result of a growing sense of trust developing between the child and the criminal, the child can thus be persuaded that the relationship should be kept secret. One of the approaches of the pedophile will involve persuading the child that his/her parents would be upset if they knew that he/she had so much fun with someone other than his/her parents. Again, by manipulating the child's need to feel loved and accepted, the child will be persuaded that his/her parents would not agree and put an end to this developing friendship relationship, thus preventing them from interacting in the future. Another version of this approach could consist in the criminal making gifts to the child, subsequently trying to persuade him/her that his/her parents would be angry or jealous if they knew he/she had received gifts [2]. It is also possible for the pedophile to send pornographic materials to the child in order to gradually desensitize him/her to their sexual content [3].

Such pornographic content is usually presented in a gradual manner. The first images consist of pictures showing children in various stages of undressing. These pictures might also include nude children. Such pictures are used in order to convince the child that being undressed in front of others is an acceptable behaviour. The next level of images will consist of picture of nude children touching one another. These pictures will, of course, be used in order to convince the child that there is nothing wrong with the fact that several naked children touch one another. Once the pedophile considers that a child accepts those images, the victim will receive the final series of images. These final pictures will present children who have sexual relationships with an adult. In general, after this stage/level, the pedophile will try to initiate a sexual relationship with the child.

From the moment the child starts feeling at ease with the pedophile, the offender will be able to move on to the next level, that of seduction. Once the pedophile thinks the relationship will be kept secret, he will try to determine the level of the emotional bond established between himself and the child.

If he considers that a significant relationship has developed, he might proceed to initiating physical contact. The first such contacts are usually of lesser significance, often involving touching or rubbing. A lot of children do not even realize that they are being touched by their "friend" in a negative or inappropriate manner. Many pedophiles will try to present those first touches as accidental contacts. From the moment physical contact begins, it will only be a matter of time before the child becomes susceptible for more advanced physical contact, such as sexual activity [4].

\section{Child pornography as regulated by the Romanian Criminal Code 2.1. Legal content}

Art. 374. (1) The production, possession for display or distribution, the acquisition, storage, display, promotion, distribution and supplying, in any manner, of child 
pornography shall be punishable by no less than 1 and no more than 5 years of imprisonment.

(2) If the acts set out in par. (1) are committed using a computer system or other means of data storage, it shall be punishable by no less than 2 and no more than 7 years of imprisonment.

(3) The act of unlawfully accessing child pornography through computer systems or other means of electronic communication shall be punishable by no less than 3 months and no more than 3 years of imprisonment or by a fine.

(4) Child pornography means any material that shows a juvenile displaying a sexually explicit behaviour or that, even if not presenting a real person, simulates a juvenile with such behaviour in a credible manner.

(5) The attempt shall also be punishable.

\subsection{The New Criminal Code in relation to the previous criminal law}

The previous criminal code, dating back to 1969, does not criminalize such an offence, which was only incriminated after year 2000 by special laws, such as Law no. 678/2001 on preventing and combating trafficking in human beings [5], Law no. 196/2003 on the prevention and combating of pornography [6], Law no. $161 / 2003$ on certain measures for ensuring transparency in the exercise of public dignities and offices, and in the business environment, for preventing and punishing corruption [7].

The criminalization of the criminal offence of pornography in the new Criminal Code aimed at eliminating regulatory overlaps caused by the existence of several regulatory acts, but also at implementing a number of European instruments that impose the obligation to sanction certain behaviours related to the problem of child pornography, such as the Council of Europe Convention on Cybercrime of $23^{\text {rd }}$ November 2001 and the Framework Decision of the Council of the European Union no. 1004/68/JHA of $22^{\text {nd }}$ December 2003.

\subsection{Concept and characterization}

The existence of pornographic materials with juveniles on the market has generated a strong concern at national and international level, aimed at discouraging and sanctioning the circulation of such materials. The extremely aggressive campaign against this scourge, the activity of international governmental and nongovernmental organizations directed towards this purpose, as well as a number of cases brought before the law courts in various countries, have also led to an offensive against freedom of expression. However, child protection cannot be regarded as a censorship issue. The creation of a safe environment for children must preserve and develop fundamental freedoms, such as the freedom of expression, the right to information and the protection of the intimate sphere, while 
also protecting children in the face of illegal and harmful content. Freedom of expression must be subject to extreme rigors, especially since cyberspace is the place where pedophiles are provided with vast opportunities to exchange ideas, fantasies and advice, meant to encourage and facilitate the sexual exploitation of minors [8]. The criminalization of pornography in the Romanian criminal legislation meets the obligations undertaken by Romania through international conventions, and as a new regulatory variant, the Criminal Code criminalizes the unlawful access to pornographic materials involving minors through computer systems or other electronic communication means, a variant that was not present in the special laws mentioned above [9].

\subsection{Pre-existing elements}

A. The specific legal object consists in the social relations regarding public order and peace, the protection of a person's dignity, of public modesty and morality, which can be breached by obscene manifestations affecting good morals.

Pornographic materials involving minors can cause certain people to experience impulses that are not in accordance with good morals. At the same time, child pornography acts prejudice, in general, "the right to image" and "the minor's dignity". In particular, the minor who is the subject of pornographic images may suffer deep psychological trauma [10].

$\mathrm{B}$. The material object of the criminal offence is the material medium on which pornographic images of minors are fixed or computer systems, in the case of child pornography by computer means. According to the doctrine, computer systems are a complex and dynamic set of resources, users and processes, whether automated or manual, organized for the collection, processing, maintenance, use or dissemination of information [11]. In terms of the legal definition, the Romanian legislator decided that a computer system should be understood to mean any device or set of devices that are interconnected or in a functional relationship, one or more of which provide automatic data processing by means of a computer program.

A data storage medium is any device that allows for the storage of computer data, whether it is a fixed storage unit (HDD, SSD), or a mobile storage unit (CD, DVD, memory stick). Electronic means of communication are electronic equipment and cable, optical fibre, radio, satellite networks, etc., used for processing, storing or transmitting information.

C. Subjects of the criminal offence

a) The direct active subject of the criminal offence of child pornography may be any natural person, no special capacity being required by the incriminating text for the active subject.

Criminal participation is possible in all forms, namely as a co-perpetrator, instigator or accomplice. 
A legal entity may be the subject of the offence of child pornography insofar as the natural persons who might trigger its criminal liability perform any of the activities incriminated by Art. 374 [12].

b) The passive subject of the offence is the State, in its capacity as a guarantor of public order and peace. It is obliged to ensure the health of minors and their normal psychosocial development.

Criminal offences may also involve a secondary passive subject, in the person of a minor who was involved in the production of pornographic materials and whose images were displayed, broadcast or distributed.

\subsection{Structure and legal content of the criminal offence}

A. The premise situation

There is no premise situation in the case of this crime.

B. The constitutive content of the offence comprises: a) the objective side; b) the subjective side.

a) The objective side comprises the material element, the essential requirements, the immediate follow-up and the causal link.

The material element of the objective side of the offence in the typical form and the aggravated form is accomplished through similar actions, the difference consisting in the fact that, in case of the aggravated form, the actions are performed by means of a computer system or another data storage medium [13].

The offences mentioned above have an alternative content in terms of the methods of committing them, meaning that the carrying out of any of the actions stipulated by the incriminating rule leads to the consummation of the crime.

The repeated committing of multiple actions, from among those mentioned in the incriminating rule, based on the same criminal resolution, turns the offence into a continuing crime.

Production consists of manufacturing or combining images or other representations of one or more minors involved in explicit, real or simulated sexual activities, or images or other representations of a minor's sexual organs, represented in a lewd or obscene manner, including in an electronic format [14]. In this case, all persons involved in the production of pornographic materials are co-perpetrators.

Possession, as a method of committing the offence, should be aimed at displaying or distributing such materials. The action consists in the mere fact of holding such materials under any title, whether or not they belong to the perpetrator, the essential requirement being that the purpose of holding them is to display or distribute such materials. It is not relevant where the materials are held, whether they are found in private spaces, upon the perpetrator or in a hidden place, regardless of whether or not the perpetrator was able to display or distribute the pornographic materials depicting minors. The purpose of the action of holding such 
materials might become apparent from the perpetrator's attitude, the number of copies held and other such circumstances [15].

The acquisition of materials with pornographic content consists of any onerous or gratuitous (for valuable consideration or free of charge), permanent or temporary acquisition of photographs, films, publications or other means of explicitly expressing or suggesting sexual activity with minors.

The storage of materials with pornographic content involving minors is the action of storing in the memory of a system a certain amount of information containing photographs, publications, video recordings that have such content.

The display action is achieved by placing or posting a pornographic material involving minors on a computer medium so that it can be accessed by others.

The promotion of pornographic materials involving minors is the action of spreading such materials through advertisements or any publicity materials that would refer to marketing, display or production sites, websites where such materials can be accessed [16].

Distribution consists in providing, in any way, for valuable consideration or free of charge, access to images or other representations of one or more minors involved in explicit, real or simulated sexual activities, or to images or other representations of the sexual organs of a minor represented in a lewd or obscene manner, including in electronic format [17].

It is irrelevant to the existence of the offence whether or not all such acts were committed in relation to a minor who wanted to participate in the production of pornographic materials. The type of medium on which the representation of minors was fixed (paper or even electronic format) is also irrelevant [18].

The action of making materials available means the assurance, by any means, of access, whether for valuable consideration or free of charge, to pornographic materials depicting minors, and the possibility for people to use such materials. In the case of sale of such materials, it is indifferent whether the sale is face-to-face or clandestine, and whether the person who buys that material intends to resell it or to keep it [19].

Access is the action of entering a network or a program.

"Minors" shall mean individuals who have not reached the age of 18 years, regardless of their gender, state of health (disability), nationality, citizenship, social origin, wealth or school education level.

Immediate follow-up. The commission of any of the incriminated activities has the immediate consequence of creating a state of danger for good morals, given that pornographic materials have the potential to pervert the moral sense, as well as the sexual instinct.

The causal link results from the materiality of the fact itself. 
Drăgan A.T. (2018)

Child pornography and child abuse in cyberspace

b) The subjective side of the offence is achieved by committing the incriminated actions, with direct or indirect intent.

The perpetrator should grasp the fact that the persons who have been exposed or have exposed their own bodies in view of producing such materials are minors. The consent of the person concerned does not constitute a justifiable cause [20].

Actions committed by fault do not make up the contents of these offences.

\subsection{Forms. Methods. Sanctions}

\section{A. Forms}

a) Preparatory acts are possible, but not incriminated.

b) The attempt is possible and is sanctioned, being criminalized by Art. 374 par. (5).

c) Consummation of the offence. The offence under analysis is consummated when the perpetrator has produced, held in view of display or distribution, acquired, stored, displayed, promoted, distributed, made available in any way pornographic materials depicting minors.

The criminal offence is also susceptible to be committed in a continued form, when multiple actions are committed at different times in the execution of the same criminal resolution.

\section{B. Methods}

a) Regulatory methods

The act is incriminated in the typical variant, an aggravated variant and a mitigated variant.

b) Factual methods

The criminal offences may be committed through a variety of concrete ways to produce, hold for display or distribution, acquire, store, display, promote, distribute, and make available pornographic materials or access to computer systems.

\section{Sanctions}

The typical variant of the offence is punishable by imprisonment from one year to five years. The punishment for the aggravated variant is imprisonment from 2 to 7 years. The attenuated (mitigated) variant is punishable by imprisonment from 3 months to 3 years or by fine.

\section{Protecting children in cyberspace}

It is considered [21] that there are some basic measures that should be adopted in order to protect children when they are online:

- placing the computer in a common area of the home rather than in the child's bedroom; 
Child pornography and child abuse in cyberspace

- having discussions with the child about the dangers that might be encountered in cyberspace;

- limitation of the time the child can spend surfing the internet;

- having discussions with the child about the appropriate use of social networks;

- preventing the child from posting pictures of him/her on the Internet;

- using the parental control mode provided by certain antivirus applications, which allows creating a list of blocked websites in order to avoid the inappropriate use thereof.

\section{Conclusions}

Sexual exploitation of children and child pornography are extremely serious violations of human rights and of the child's fundamental right to a harmonious education and development, and the criminalization of this kind of pornography in Romanian criminal legislation meets the obligations undertaken by Romania through international conventions.

\section{References}

1. Robert Moore, Cybercrime. Investigating high-technology computer crime, second edition, Anderson Publishing, Oxford, 2011

2. Grainne Kirwan, Andrew Power, Cybercrime. The Psychology of online offenders, Cambridge University Press, 2013

3. Sergiu Brînză, Vitalie Stati, Tratat de drept penal. Partea specială (Criminal Law Treatise. The Special Part), Vol. I, Tipografia Centrală (Central Printing House), Chișinău (Kishinev), 2015

4. George Antoniu, Tudorel Toader et al., Explicațiile noului Cod penal (New Criminal Code Explanations), Vol. V, Ed. Universul Juridic (Publishing House), Bucharest, 2016

5. Vasile Dobrinoiu, Ilie Pascu et al., Noul Cod penal comentat. Partea specială, Ediția a II-a, revăzută și adăugită (The New Criminal Code, Commented. The Special Part), 2nd edition, revised and enlarged), Ed. Universul Juridic (Publishing House), Bucharest, 2014

6. Marin Ruiu, Metodologia investigării criminalistice a unor genuri de infracțiuni (Methodology of Forensic Investigation of Certain Types of Crimes), Ed. Universul Juridic (Publishing House), Bucharest, 2014

7. Petre Dungan, Tiberiu Medeanu, Viorel Pașca, Drept penal. Partea specială ((Criminal Law. The Special Part), Vol. II, Ed. Universul Juridic (Publishing House), Bucharest, 2013

8. Alexandru Ionaș, Alexandru Florin Măgureanu, Cristina Dinu, Drept penal. Partea specială (Criminal Law. The Special Part), Ed. Universul Juridic (Publishing House), Bucharest, 2015

9. Vasile Dobrinoiu, Norel Neagu, Drept penal. Partea specială (Criminal Law. The Special Part), Ed. Universul Juridic (Publishing House), Bucharest, 2014

10. Felicia Donovan, Kristyn Bernier, Cyber crime fighters. Tales from the trenches, QUE Publishing, Indianapolis, Indiana, 2009

\section{Notes}


Drăgan A.T. (2018)

Child pornography and child abuse in cyberspace

1. Robert Moore, Cybercrime. Investigating high-technology computer crime, second edition, Anderson Publishing, Oxford, 2011, pp. 83-84

2. R. Moore, op. cit., pp. 84-85

3. Grainne Kirwan, Andrew Power, Cybercrime. The Psychology of online offenders, Cambridge University Press, 2013, p. 133

4. R. Moore, op. cit., p. 85

5. Published in the Official Journal no. 783 of $11^{\text {th }}$ December 2001

6. Published in the Official Journal no. 342 of $20^{\text {th }}$ May 2003

7. Published in the Official Journal no. 279 of $21^{\text {st }}$ April 2003

8. Sergiu Brînză, Vitalie Stati, Tratat de drept penal. Partea specială (Criminal Law Treatise. The Special Part), Vol. I, Tipografia Centrală (Central Printing House), Chișinău (Kishinev), 2015, p. 1059

9. George Antoniu, Tudorel Toader et al., Explicațiile noului Cod penal (New Criminal Code Explanations), Vol. V, Ed. Universul Juridic (Publishing House), Bucharest, 2016, p. 57

10. Vasile Dobrinoiu, Ilie Pascu et al., Noul Cod penal comentat. Partea specială (The New Criminal Code, Commented. The Special Part), 2nd edition, revised and enlarged, Ed. Universul Juridic (Publishing House), Bucharest, 2014, p. 884

11. Marin Ruiu, Metodologia investigării criminalistice a unor genuri de infracțiuni (Methodology of Forensic Investigation of Certain Types of Crimes), Ed. Universul Juridic (Publishing House), Bucharest, 2014, p. 23

12. Petre Dungan, Tiberiu Medeanu, Viorel Pașca, Drept penal. Partea specială (Criminal Law. The Special Part), Vol. II, Ed. Universul Juridic (Publishing House), Bucharest, 2013, p. 343

13. G. Antoniu, T. Toader, op. cit., p. 58

14. S. Brânză, V. Stati, op. cit., p. 1062

15. Ibidem, p. 59

16. P. Dungan, T. Medeanu, V. Pașca, op. cit., p. 344

17. S. Brînză, V. Stati, op. cit., p. 1063

18. Alexandru Ionaș, Alexandru Florin Măgureanu, Cristina Dinu, Drept penal. Partea specială (Criminal Law. The Special Part), Ed. Universul Juridic (Publishing House), Bucharest, 2015, p. 604

19. Vasile Dobrinoiu, Norel Neagu, Drept penal. Partea specială (Criminal Law. The Special Part), Ed. Universul Juridic (Publishing House), Bucharest, 2014, p. 696

20. G. Antoniu, T. Toader, op. cit., p. 60

21. Felicia Donovan, Kristyn Bernier, Cybercrime fighters. Tales from the trenches, QUE Publishing, Indianapolis, Indiana, 2009, p. 146 